zła od pożytku dobra. Dlatego to u podstaw chrześcijańskiej doskonałości leży zawsze czystość serca (s. 67).

Leander Tadeusz Pietras OSPPE,

Vranov nad Topl'ou, Słowacja

\title{
Allan D. FITZGERALD O.S.A. (red.), Diccionario de san Agustín. San Agustín a través del tiempo, Burgos 2001, Wyd. Monte Carmelo, ss. $1352+$ LVI.
}

Z pewnością warto odnotować pojawienie się na europejskim rynku księgarskim tłumaczenia, nie tak dawno wydanej w Stanach Zjednoczonych, pozycji encyklopedycznej poświęconej jednemu z największych Ojców Kościoła św. Augustynowi [oryg.: Augustine through the Ages. An Encyclopedia. William B. Eerdmans Publishing Co., Grand Rapids, 1999]. Postać, której przybliżenie czytelnikowi postawili sobie za cel autorzy, nie wymaga przedstawiania. Św. Augustyn (354-430), od 395 biskup w Hippo Regius (na terenie dzisiejszej wschodniej Algierii), jeden z najpłodniejszych autorów starożytności chrześcijańskiej, niewątpliwie jedna z czołowych postaci złotego wieku patrystyki i całej historii myśli chrześcijańskiej.

Autorzy, to międzynarodowa grupa ok. 130 osób z różnych ośrodków akademickich, głównie ze Stanów Zjednoczonych, specjalistów w zakresie patrologii, studiów klasycznych, teologii, także historii, filozofii i nauk politycznych, zgromadzona pod przewodnictwem A. Fitzgerald'a, dyrektora Augustinian Studies w Uniwersytecie Villanova (USA), i od 1998 r. wykładowcy w Instytucie Patrystycznym Augustinianum w Rzymie. Zaproszenie do tego grona takich osób, jak Angelo di Berardino czy Vittorino Grossi z pewnością podnosi prestiż wydawnictwa i świadczy o tym, iż redaktorzy próbowali stworzyć dzieło na wysokim poziomie. Czy zamierzenie to udało się zrealizować?

Szeroki wachlarz podjętych zagadnień poruszanych w słowniku można podzielić na kilka części. Niewątpliwym atutem jest część, którą możemy nazwać bibliograficzną, odnosząca się bezpośrednio do twórczości pisarskiej Augustyna. Już u początku książki napotykamy na dwie przejrzyste tabele (s. XLILXI) zawierające spis dzieł Biskupa Hippony (tytuły łacińskie i hiszpańskie), ich powszechnie używane skróty, adnotacje o wydaniach tekstów oryginalnych (w seriach PL, CCL i CSEL) i tłumaczeniach hiszpańskich, referencje dotyczące dat powstania poszczególnych pism i - w wielu wypadkach - uwagi oraz odnośniki bibliograficzne. Oprócz tego interesującą tabelę bibliograficzną spotykamy w opracowaniu R. Eno, dotyczącym augustyńskiej spuścizny epistolarnej (s. 468-474) - zawiera spis listów, numerację, wykaz wydań krytycznych, daty powstania oraz imiona adresatów - i kolejną w artykule E. Rebillarda 
dotyczącym mów wielkiego Teologa (s. 1200-1215) - ta mieści w sobie numerację mów, kolekcje, wydania, oraz miejsca i przybliżone daty wygłoszenia. Tabele jednak to tylko mała cząstka tej materii. Słownik zawiera bowiem ponad sto artykułów, w których omówiono najważniejsze dzieła Doktora Kościoła. Obok tytułów dotyczących konkretnych dzieł, umieszczone zostały także takie, które ukazują wizję ogólną niektórych szerzej potraktowanych zagadnień obecnych w twórczości Biskupa Hippony (np. omawiające literaturę antyariańską, antypelagiańską, antymanichejską czy antydonatystyczną). Właściwie zbiór jedynie tych artykułów mógłby stanowić odrębną i bardzo ciekawą pozycję. Wszystkie tytuły zawierają omówienie odnośnych dzieł, ukazują kontekst historyczny ich powstania, są zaopatrzone w wykazy edycji i aktualnej bibliografii. Twórcy słownika pomyśleli nawet o dodaniu dosyć dużego i zaopatrzonego w szeroki wykaz bibliografii artykułu na temat manuskryptów pism Augustyna.

Zapoznawszy się z tytułami i zawartością dzieł, użytkownik słownika może poznać także zarys myśli i doktryny wielkiego Biskupa. Autorzy omawiają, niekiedy bardzo szczegółowo, augustyńską wizję duchowości oraz większość zagadnień dogmatycznych, moralnych i filozoficznych, które znaleźć można w dziełach świetęgo Afrykańczyka. Oprócz tego napotykamy na kilka tekstów dotyczących kwestii biblijno-egzegetycznych, od najbardziej ogólnych (np. Biblia), po szczegółowe, odnoszące się do niektórych postaci biblijnych, czy sposobów interpretacji tekstu. Nie brakuje również kilku tytułów z zakresu problematyki społecznej a nawet polityki. Ta część, zresztą zajmująca większość miejsca w słowniku, stanowi bardzo celnie opracowany zbiór, dający możliwość wniknięcia w doktrynę uczonego Biskupa, w jego metody, w sposób widzenia Boga, świata, człowieka. Nie sposób wymienić wszystkich zagadnień, dość jednak rzec, że trudno znaleźć jakiś ważniejszy temat, który byłby obecny w twórczości św. Augustyna, a którego by nie poruszono w omawianym dziele.

Twórcy słownika nie pominęli także faktu, iż ten Ojciec Kościoła, którego portret chcieli nakreślić, nie żył w świecie hermetycznym, lecz był otwarty tak na wpływy - będącej już w stanie rozkwitu - myśli chrześcijańskiej, jak i kultury klasycznej. Wyrazem tego jest zamieszczenie grupy artykułów, w których omówiono relacje pomiędzy myślą augustyńską a twórczością wcześniejszych Ojców i pisarzy kościelnych oraz autorów pogańskich. Możemy korzystać przykładowo z referencji dotyczących ludzi Kościoła starożytnego, jak Orygenes, Tertulian, św. Ambroży, św. Cyprian, św. Hieronim, Ojcowie Kapadoccy. Mamy również możliwość sięgnięcia do haseł odnoszących się do Arystotelesa, Platona, Cycerona czy Wergiliusza. Zbiór haseł szczegółowych ubogacono dwoma dobrymi opracowaniami generalnymi, dotyczącymi zarówno wpływów klasycznych (s. 708-718), jak wczesnochrześcijańskich (s. 718-726). Z drugiej strony nie brak także opracowań kwestii wpływu św. Augustyna na potomność. 
Napotykamy przeto pokaźny zbiór odnośników dotyczących oddziaływania myśli Hippończyka na późniejszą doktrynę patrystyczną, średniowiecze, a nawet myśl nam współczesną. Obok haseł Grzegorz I czy Izydor z Sewilli, spotykamy takie jak Tomasz z Akwinu, Grzegorz z Rimini, by w końcu odnaleźć referencje do autorów nowożytnych, jak von Harnack, Heidegger, Kierkegaard i wielu innych. Możemy znaleźć artykuły dotyczące obecności augustyńskiej myśli na synodach i soborach (np. Orange, Trydent), czy jej wpływu na Reformację (Augustynizm w Reformacji, Kalwin, Luter). Także i tutaj nie brakuje opracowań bardziej ogólnych. Warte wspomnienia są np. ciekawe artykuły dotyczące oddziaływania myśli wielkiego Biskupa na V wiek, czy na erę karolińską.

W dziele dotyczącym św. Augustyna nie mogło oczywiście zabraknąć elementów biograficznych. Umieszczono przeto kilka artykułów dotyczących życia Ojca Kościoła, rodziny, czy ludzi z nim związanych (np. Alipiusz, Possydiusz). Ale i to jeszcze nie wszystko. Opisano bowiem także środowisko, w którym żył słynny Afrykańczyk, tak pod względem historycznym (Kościół północnoafrykański), jak i geograficznym (Hippona, Kartagina), a nawet poruszono kwestię badań archeologicznych w Numidii.

Oprócz referencji merytorycznych, znajdujemy także dodatki, jak alfabetyczny spis haseł otwierający książkę, różny od indeksu umieszczonego na jej końcu (można spierać się o zasadność jego istnienia, ale przy wydawnictwie tej wielkości okazuje się on ułatwieniem dla korzystającego), listę współautorów wraz z informacjami o ośrodkach, w których pracują, oraz wykaz bibliografii ogólnej (chyba celowo niezbyt imponujący, czego bowiem nie ma tutaj, to w obfitości umieszczono przy końcu niemal każdego z artykułów).

Niewątpliwym plusem jest, iż opracowania poszczególnych tematów nie tylko zawierają informacje o augustyńskiej wizji danego problemu, ale ukazują ją w szerszym kontekście historyczno-doktrynalnym. Nadto umieszczenie, obok tematów szczegółowych, opracowań natury ogólnej poszerza perspektywę i pozwala na ogląd omawianej tematyki w sposób jaśniejszy. Czytelnik, zwłaszcza stawiający pierwsze kroki na drodze poznania wielkiego Ojca Kościoła, może zawsze zapoznać się z ową wizją perspektywiczną, by dopiero z tego punktu przystąpić do lektury kwestii szczegółowych. Takie ujęcie czyni ze słownika ważny i potrzebny instrument dla zainteresowanych generalnie patrystyką czy historią oraz pomoc tak dla studentów, jak i zaawansowanych badaczy myśli św. Augustyna. Bogata baza bibliograficzna potęguje jeszcze ów efekt, podnosząc wartość całego dzieła, a dodane do artykułów odsyłacze ułatwiają poruszanie się po jego rozległym i urozmaiconym terenie. Nie sposób pominąc elementu estetycznego, twarda oprawa i schludna szata graficzna powodują, że książka, sama w sobie cenna, nadto okazuje się ładna.

Oczywistym jest, że - jak prawie każde dzieło - słownik posiada też pewne minusy. Można było np. zdecydowanie szerzej potraktować zagadnienia bib- 
lijne. $\mathrm{Z}$ drugiej jednak strony, są one w jakiś sposób obecne w innych artykułach, szczególnie dotyczących augustyńskich komentarzy do Pisma św. Być może warto pogłębić niektóre noty, czy zaopatrzyć je w obfitszą bibliografię. Spotykamy np. intrygująco brzmiący tytuł Augustyn w cyberprzestrzeni. Spodziewać się w nim możemy szczegółowych odnośników, adresów internetowych, tymczasem napotykamy na bardzo ogólne opracowanie. Można jakoś usprawiedliwiać autora amerykańskiego, który pisał swój artykuł kilka lat temu, ale redaktorzy wersji hiszpańskiej mogli pomyśleć o jego uzupełnieniu. Być może można też dodać opracowania jeszcze kilku tematów, ale uczynienie tego spowodowałoby nadmierny rozrost książki, która i tak liczy prawie półtora tysiąca stron, oraz otworzenie perspektyw, które znowu domagałyby się tworzenia kolejnych haseł.

Nieliczne negatywy nikną jednak w świetle dogłębnie przemyślanej całości. Słownik jawi się metodycznie opracowanym dziełem, które daje pełen ogląd życia i myśli św. Augustyna oraz jego wpływu na teologię i filozofię. Wypełnia ono lukę pomiędzy wielkimi, często trudno dostępnymi pozycjami w rodzaju Augustinus-Lexicon, a mniejszymi i zbyt ogólnymi - konkretne przykłady pominę - które służą (i bardzo dobrze) raczej pobożnym poszukiwaczom wzorów świętości, niż studentom czy wykładowcom. Powyżej postawiono pytanie o poziom dzieła. Tu można dać odpowiedź jedynie pozytywną. W tym kontekście nie dziwi opinia J. Pelikana, umieszczona w przedmowie Stownika, iż jest dla niego honorem i przyjemnością zarekomendowanie go czytelnikom.

Ks. Jerzy Lachowicz - Białystok

\section{Leon NIEŚCIOR, Asceza chrześcijańska i filozofia w pismach Nila z Ancyry, Poznań 2001, Uniwersytet im. Adama Mickiewicza w Poznaniu. Wydział Teo- logiczny, ss. 280.}

Nil z Ancyry należy do tych autorów wczesnochrześcijańskich, których autentyczność niektórych dzieł jest do dziś mocno kwestionowana. Może też dlatego nie cieszył się on w Polsce zbyt wielkim zainteresowaniem wśród badaczy antyku chrześcijańskiego, mimo iż należy niewątpliwie do jednych z największych mistrzów życia duchowego w starożytności na Wschodzie. $\mathrm{Z}$ przekładów jego pism możemy raptem wymienić fragment traktatu $O$ dobrowolnym ubóstwie, anonimowego tłumacza („Szkoła Chrystusowa” 1:1930, t. 1, 85-88), kilkadziesiąt listów w przekładzie prof. L. Małunowiczówny (STCh II 291-323), oraz fragmenty Mowy ascetycznej w tłumaczeniu A. Bobera SJ („Znak” 26:1974, nr 240, 829). Natomiast listę opracowań otwiera właśnie niniejsze studium, które stanowi pierwszy poważny przyczynek naukowy na gruncie polskim na temat mnicha z Ancyry. Ten wykaz zamyka jak dotychczas 